\title{
Comparison with GW predictive modelling, pilot tests and design of an injection hydraulic barrier
}

\author{
A. Amantia ${ }^{1}$, P. Bendotti ${ }^{1}$, G. Donini ${ }^{1}$ \& M. Molinari ${ }^{2}$ \\ ${ }^{1}$ URS Corporate, Italy \\ ${ }^{2}$ ENI Refining and Marketing, Italy
}

\begin{abstract}
In March 2004 the Italian Environmental Protection Agency (APAT) and the Environmental Minister approved the largest Italian injection hydraulic barrier to protect the sea and the local coastline by LNAPL migration out of a refinery located in south eastern Sicily (Italy).

The barrier consists of $65,20 \mathrm{~m}$ deep, injection wells and 9 pumping wells at the end points located along a $1500 \mathrm{~m}$ long stretch of coastline; fresh water injection is predicted to have a rate ranging from 100 to $130 \mathrm{~m}^{3} / \mathrm{h}$ at depth between 2 and $20 \mathrm{~m}$ b.g.l. Pumping rates from terminal extraction wells will be about $40 \mathrm{~m}^{3} / \mathrm{h}$.

GW Modelling techniques have been used for the definition of number, distance, depth, and recharge requirements of injection wells.

An extensive ground water survey including water level measurements, EC profiles, hydraulic tests, and hydrogeochemical characterization of groundwater was conducted in order to define the aquifer properties, groundwater discharge and fresh/salt-water ratio.

Good accordance has been found between predictive modelling and effective mounding in the aquifer for the injection barrier.

Actually the front end engineering design of the barrier has been completed, 65 wells drilled and the preliminary systems are already installed.
\end{abstract}

Keywords: injection hydraulic barrier, polluted groundwater, saltwater intrusion, hydraulic pilot test. 


\section{Introduction}

The site is situated in Italy inside an industrial pole of 350 ha on the eastern part of Sicily, in this refinery there are already several pumping systems activated in order to contain principal dissolved plume of contaminants from migrating towards the coast.

The local stratigraphy is as follows:

- Limestones (age Cretacic - Miocene, 130 - 23 m.a.).

- Vulcanites (age Cretacic - Pliocene, 100 - 7 m.a).

- $\quad$ Sands and calcarenites (age Pleistocene med - upp 0,3 - 0,01 m.a).

- Filling material (age Olocene $<0,01 \mathrm{~m} . \mathrm{a}$ ).

Geology is very complex and the structural situation is characterized by Horst e Graben ENE-WSW oriented.

In order to provide final containment several solutions have been evaluated, from classic hydraulic barrier to the slurry walls. The main problem associated with the installation of a common hydraulic barrier is due to the proximity of the seaside and to the coarse filling used to design the new coastline.

The peculiar hydrogeological situation pushed us to find out a different solution: an hydraulic barrier made aut of injection wells designed in order to provide containment of the dissolved plumes and to reduce salt wedge intrusion along $1500 \mathrm{~m}$ of coastline.

\section{Hydrogeology}

The hydrogeological structure of the site is characterized by a main deep aquifer of regional interest and by several local shallow aquifers.

The deep aquifer is contained inside limestone and is supposed to have important thickness of several hundreds meters; the shallow aquifer are associated at sandstone and sands and is only 2 to 20 meter thickness.

The area has been characterized by hundreds of drillings, monitoring wells, hydraulic tests and chemical analysis. In situ permeability test were conducted in wells monitoring wells, several pumping test and injection test. The main field test was run in 10 wells for a period of two months.

Morphology of the coastline was changed by the original due to the construction of the refinery in the $1950 \mathrm{~s}$, actually the coastline is several meters far from the previous one the volume was filled with heterogeneous materials, fine to coarse sediments and debris.

Stratigraphy and historical reconstruction made it possible to understand the actual situation in terms of old coastline and filled area. 


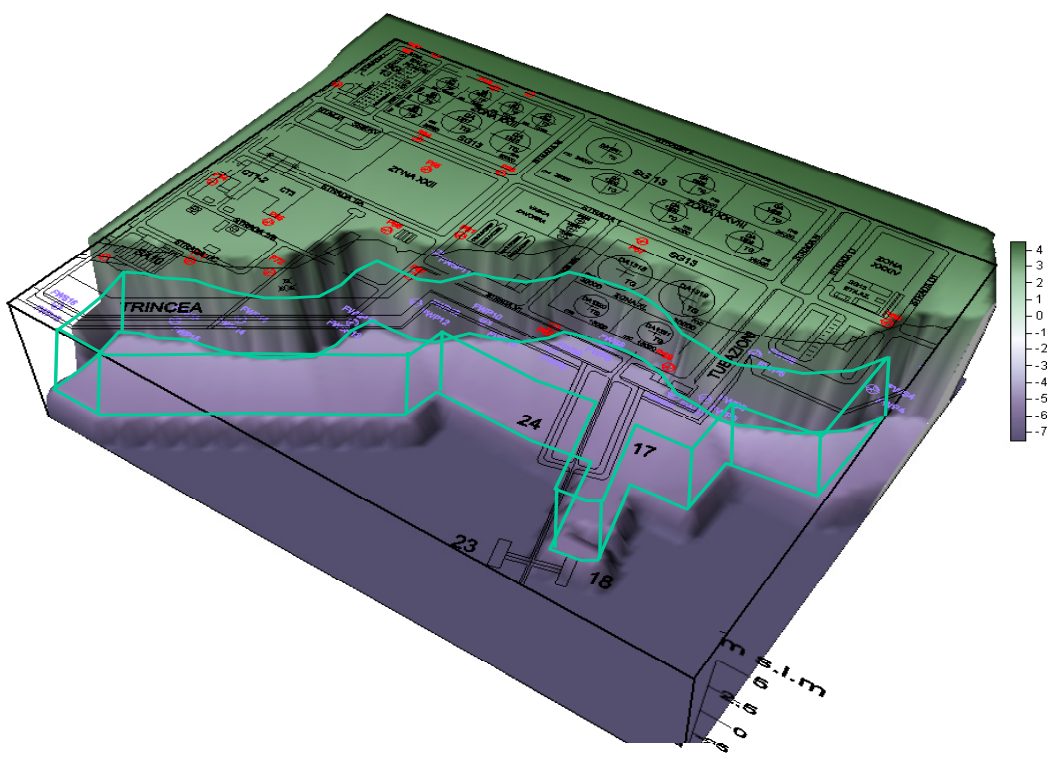

Figure 1: Old coastline and filled area.

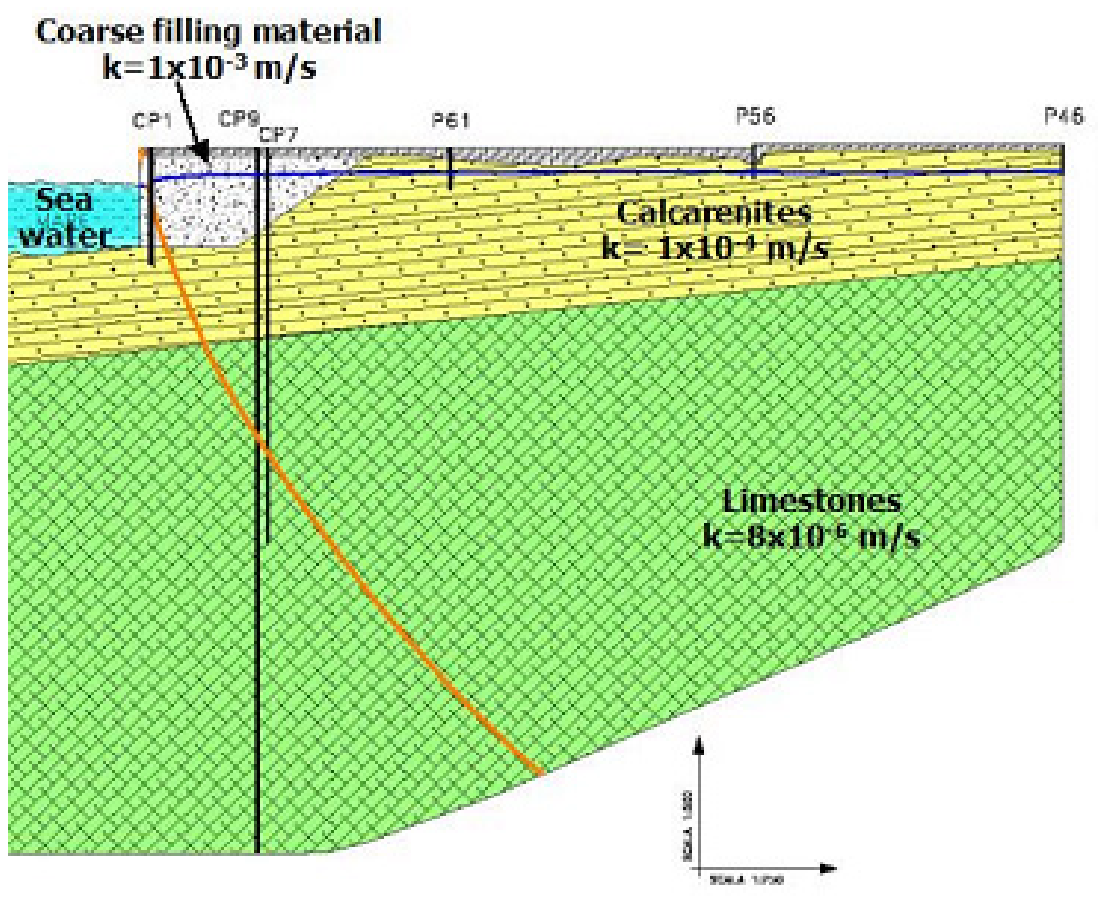

Figure 2: $\quad$ Schematic cross section of the area. 


\section{GW Modeling}

GW Modelling techniques have been used for the definition of number, distance, depth, and recharge requirements of injection wells.

An extensive ground water survey including water level measurements, EC profiles, hydraulic tests, and hydrogeochemical characterization of groundwater was conducted in order to define the aquifer properties, groundwater discharge and fresh/salt-water ratio.

The preliminary model was developed with MODFLOW $^{\circledR}$ ver. 2000 to predict fresh water mounding dynamics surrounding the barrier. The preliminary model predicted an average $40-80 \mathrm{~cm}$ mounding along the barrier line.

3 cross sections perpendicular to the coastline were developed to reconstruct salt water wedge geometry using a 2D finite elements dense dependent modelling with SUTRA [1]; subsequently, a 3D.

Model extension about $1 \mathrm{kmq}$, grid from $40 \mathrm{~m}$ x $40 \mathrm{~m}$ up to $15 \mathrm{~m} \times 15 \mathrm{~m}$ and also $5 \mathrm{~m} \times 5 \mathrm{~m}$ near the wells.

Three hydrogeological units divided into 8 layers, 204.288,00 cells.

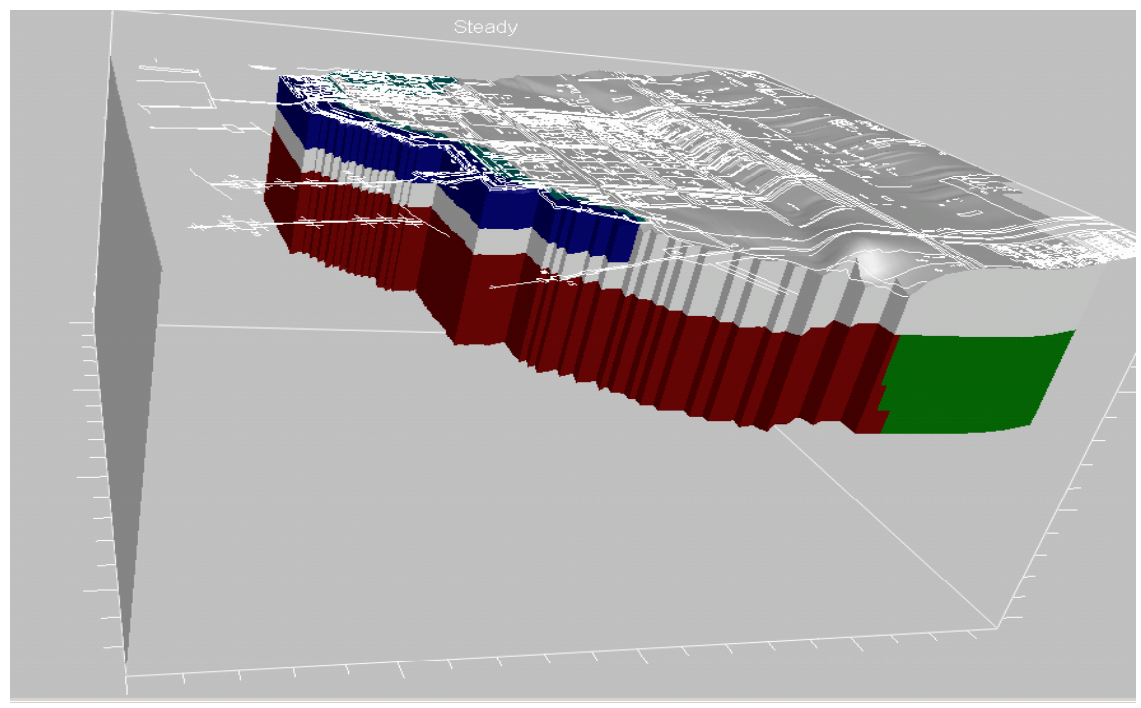

Figure 3: Model extension and different permeability zone.

Hydraulic tests were conducted at site to difine detailed parameter, keeping in consideration different factors:

- Old coastline 80 to $150 \mathrm{~m}$ western of actual coastline:

- Heterogeneous filling materials, thickness up to 8-10 m;

- Shallow aquifer out of sand and filling materials;

- Permeability vary on the vertical: 
$>$ Height, $\mathrm{k}>1 \times 10^{-3} \mathrm{~m} / \mathrm{s}$

$>$ Medium, $\mathrm{k}<1 \times 10^{-4} \mathrm{~m} / \mathrm{s}$

$>$ Low (limestone $20 \mathrm{~m}$ deep up to $60 \mathrm{~m}$ ) aquitarde $\mathrm{k}<8 \times 10^{-6} \mathrm{~m} / \mathrm{s}$

$>$ Very low (towards sea side to simulate salt intrusion) $\mathrm{K}=1 \times 10^{-9} \mathrm{~m} / \mathrm{s}$.

Model results were also used to design a pilot field test, consisting of 10 injection and 29 observation wells.

The injection pilot test was ran for a month during the period of May - June $2005 ; 20.000 \mathrm{~m}^{3}$ of fresh water was injected while water levels and salinity were constantly monitored down and up gradient along the barrier.

At the end of the test the average mounding was about $40-80 \mathrm{~cm}$ showing the consistency of the modelling work.

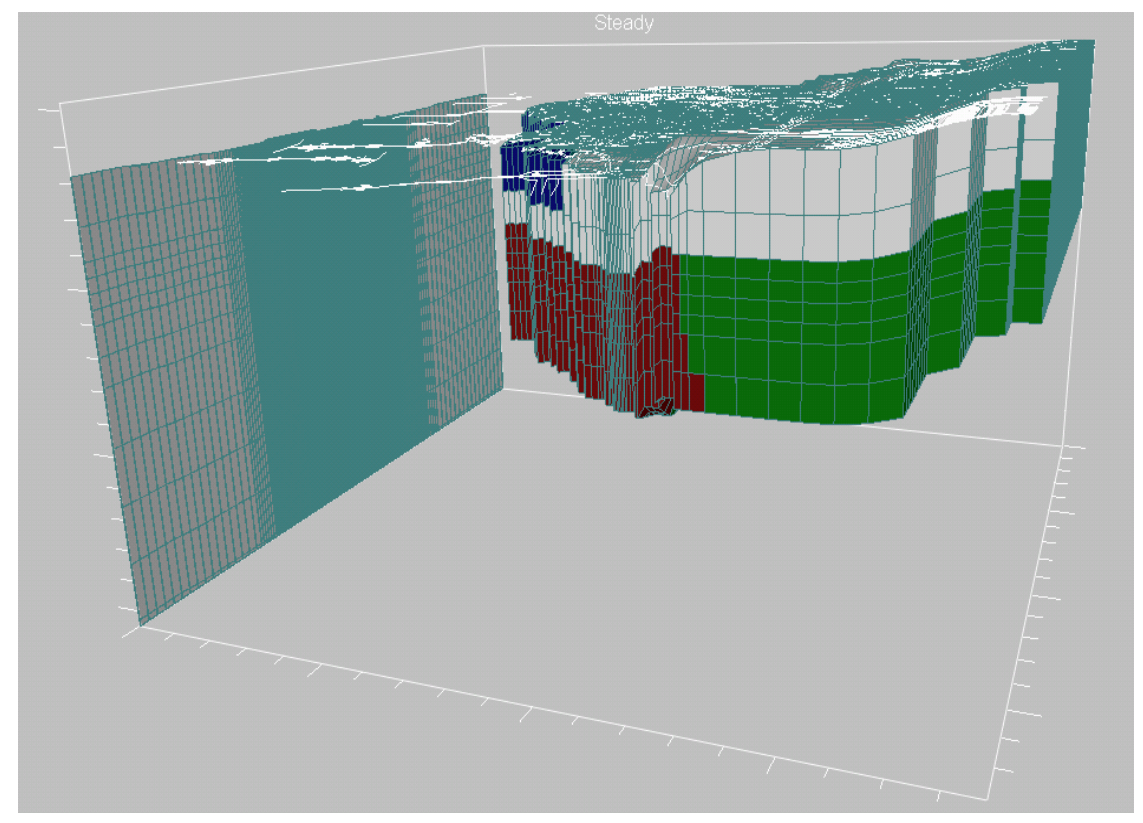

Figure 4: Model extension, grid and different permeability zone.

\section{Simulation of salt water intrusion}

The model has been developed in cooperation with Universitad Politecnica de Madrid, Prof. Elorza, using the code SUTRA (SUBSURFACE FLOW AND TRANSPORT SIMULATION MODEL) version 0690-2D;

The scheme used three different hydrogeological units: filling materials, sandstone and limestone with different permeability and hydraulic conductivity. Dimensions are $1.200 \mathrm{~m}$ by $140 \mathrm{~m}$ of deep (5000 elements of the mesh). 
Results show that salt intrusion in the deep is at least $150-170 \mathrm{~m}$ from the actual coastline while in the first $20 \mathrm{~m}$ the more permeable sediments does not allow the salt to intrude.

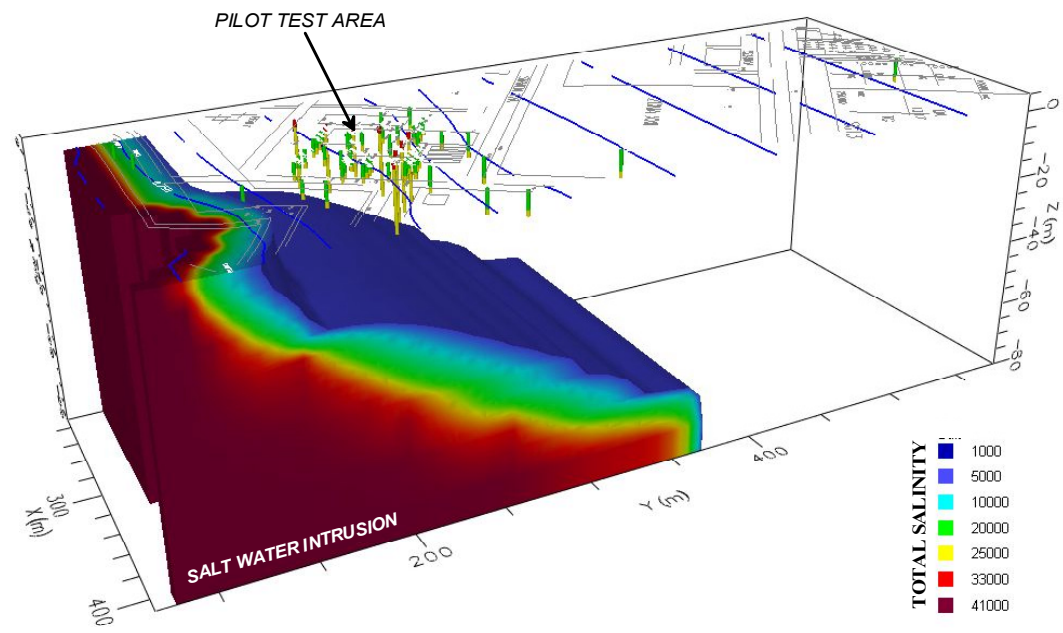

Figure 5: $\quad$ Saltwater intrusion simulated by the model.

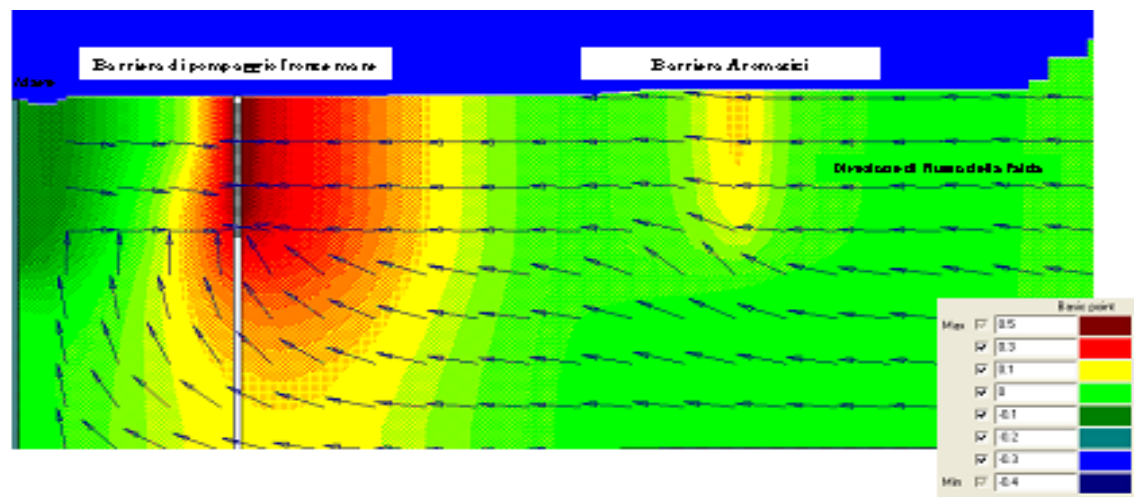

Figure 6: Groundwater circulation along the old coastline. 


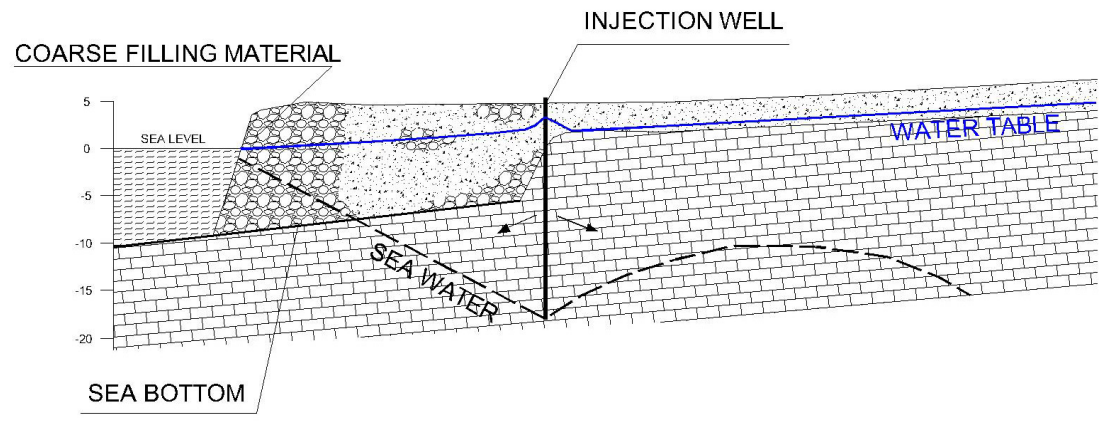

Figure 7: Circulation scheme associated with fresh water injection.

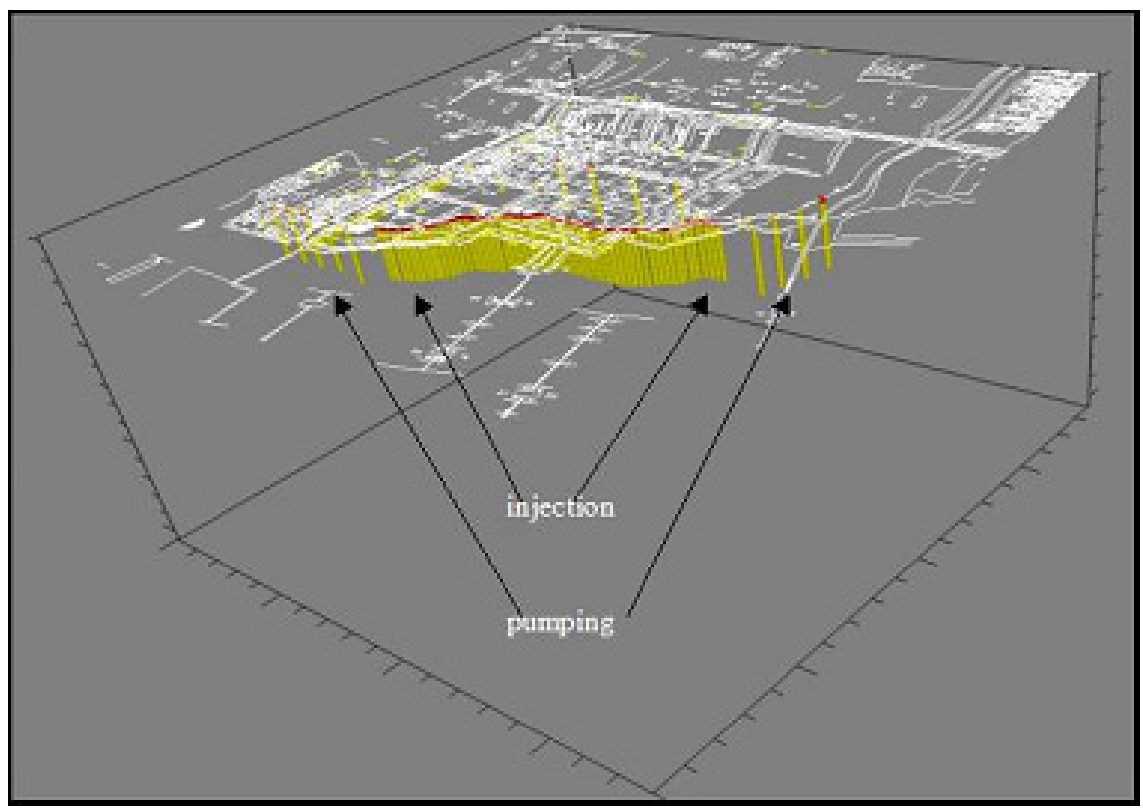

Figure 8: Configuration of injection wells and pumping wells.

The barrier consists of 65, $20 \mathrm{~m}$ deep, injection wells and 9 pumping wells at the end points located along a $1500 \mathrm{~m}$ long stretch of coastline; Fresh water injection is predicted to be at a rate ranging from 100 to $130 \mathrm{~m}^{3} / \mathrm{h}$ at depth between 2 and $20 \mathrm{~m}$ b.g.l.. Pumping rates will be about $40 \mathrm{~m}^{3} / \mathrm{h}$.

\section{Front end engineering design}

After the tests and the models we developed the front end engineering design for barrier construction. Final positions of the injections wells are shown in the 
figure 10. In the large grey area, under the tank area, we are evaluating the opportunity of installing horizontal drillings as injection wells. Actually we are running the injection tests in the horizontal drillings below this tank farm area.

A grid of monitoring wells will be installed to monitor the effects of fresh water injection inside the polluted aquifer in order to control the effects of injection and the rise of mounding along the barrier.

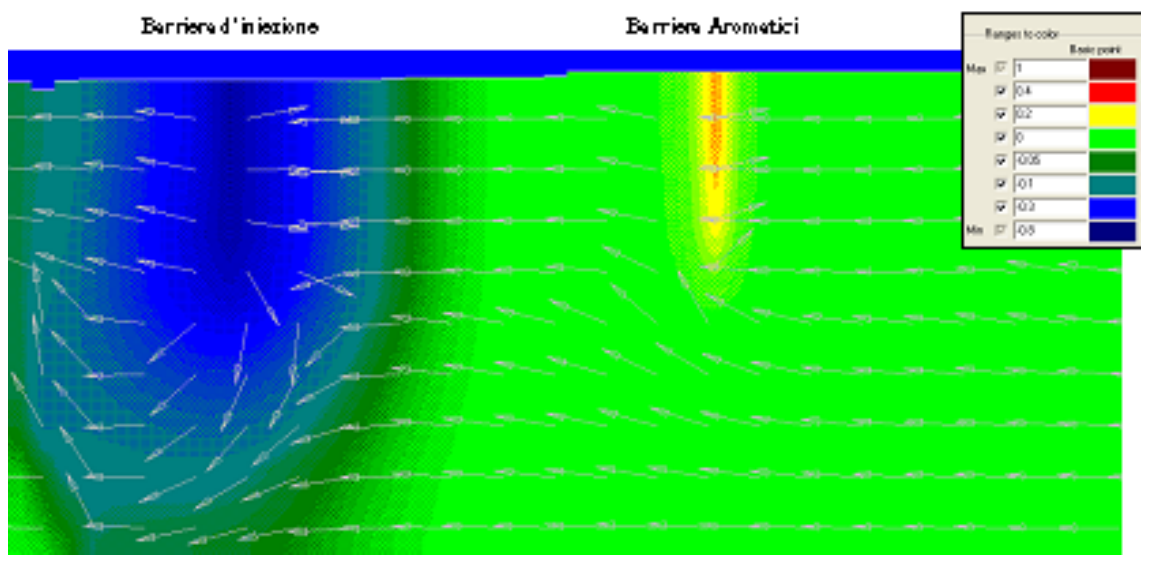

Figure 9: Effects of injection, cross section.

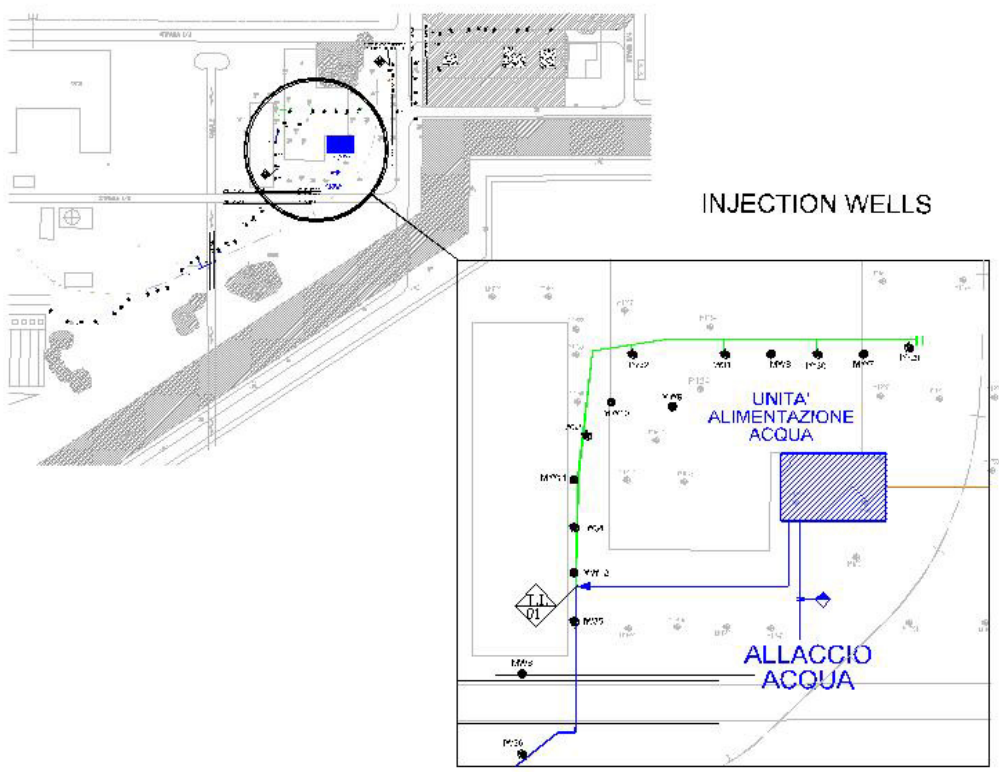

Figure 10: Front end engineering design of the injection barrier. 


\section{References}

[1] C. I. Voss. (1990) SUTRA: A finite-element simulation model for saturatedunsaturated fluid-density-dependent ground-water flow with energy transport or chemically reactive single-species solute transport. U.S, Geological Survey. Reston. Virginia.

[2] G. Donini, C. Pozzi, A. Amantia "Siti industriali inquinati in attività: applicabilità dei sistemi e delle tecnologie di bonifica e messa in sicurezza" Convegno S.E.P., Padova - Marzo 2002

[3] G. Donini, M. Goti "Impatto da radiazioni ionizzanti: indici, scale e modelli" - Politecnico di Milano - Gennaio 2001

[4] G. Donini, G. Filauro, M. Goti "Problematiche relative ad accumulo di materiali radioattivi a bassa attività ed utilizzo del software ResRad per la valutazione dei rischi associati" GEOFLUID - 2000

[5] G. Donini, M. Gambera, R. Fichera "MGP Site, caratterizzazione ambientale di una ex officina per la produzione del gas da città, raccolta ed elaborazione dei dati" GEOFLUID - 1998

[6] G. Donini, M. Gambera, S. Di Nauta, R. Fichera "Biodegradazione intrinseca e modellistica "Fate and Transport" applicati ad un caso di contaminazione da idrocarburi aromatici ed MTBE in area urbana. Da: atti del convegno "Protezione e recupero delle acque sotterranee"," Piacenza Ottobre - 1996

[7] S. Di Nauta, G. Donini, R. Fichera, M. Gambera "Soil venting/bioventing and air sparging/biosparging: air based technologies for in situ remediation of organic contaminants" Da: atti de "1st International Conference on the impact of industry on groundwater resources" Cernobbio (CO) - Maggio 1996

[8] M. Samaja, I. Bonfà, S. Di Nauta, G. Donini "Suoli e acque di falda contaminati da prodotti petrolchimici: casi di specie" Da: Atti della conferenza "Africa Needs Groundwater", Università di Witwatersrand, Johannesburg, S.A., - Settembre 1993

[9] G. Donini, G. Rossi "Karst in Mount Sedom" Congreso Internacional de Espeleologia, Barcelona, Spagna, Agosto 1986. 